\title{
Knowledge, Skills, and Attitudes as Predictors in Determining Teachers' Competency in Malaysian TVET Institutions
}

\author{
Muhd Khaizer Omar*, Farah Nadia Zahar, Abdullah Mat Rashid \\ Department of Science and Technical Education, Faculty of Educational Studies, Universiti Putra Malaysia, Malaysia
}

Received November 4, 2019; Revised December 30, 2019; Accepted January 15, 2020

Copyright $\bigcirc 2020$ by authors, all rights reserved. Authors agree that this article remains permanently open access under the terms of the Creative Commons Attribution License 4.0 International License

\begin{abstract}
Teachers' competency has sparked much interest among educational stakeholders in Malaysia. The debates among how well Malaysian teachers educate students has produced concern and become interminably reported in research. Under the government civil servants' services, teachers have been called upon to gain and bringing back this noble and reputable profession at its standard and earn the trust of parents in ensuring the success of their children at school. As part of this matter, TVET stream in Malaysia becomes sensational and selected as one of the national agendas in producing the local manpower and human capital development, where

competency level of becoming effective teachers. Notwithstanding the need for the development of skilled manpower must conclusively enlighten not only knowledge-based but also students' discovery of their skills and attitude potential especially when entering the job environment. Therefore, before proceeding with the teaching and learning environment, the teacher must first imply all these characteristics and exercise this application to students. Ultimately, the outcome from this environment will help students to venture the employment market and increase the likeliness of getting hired; locally and global job market.
\end{abstract} the spirit is to grow the young generation to become a skilled-worker in industry. Indeed, encumbrance issues such as teacher competency, program accreditation, and unemployment among graduates are among those matters mostly brought into round-table discussions and conversations among stakeholders. Therefore, this article depicted one of the issues, which is on the basis of teachers' competency and analyzed the relationship between teacher's competency traits (knowledge, skills, attitude) and teaching practices in practical-based learning and also to discover the best predictor contributed to teacher's competency measurement. A survey was distributed to 150 TVET teachers at three selected vocational colleges in Selangor. The construct of the questionnaire was adapted from prior studies and undergone a pilot study to ensure the questionnaire fit with intended research objective. The results of the study revealed that knowledge, skills, and attributes have played a major role in ensuring the competency level of Teachers. Along with the findings, the knowledge of the teachers was found the most critical factor to describe TVET teacher's competency. The implication of the results suggested that holistic traits of teacher that in knowledge, skills, and attitudes inclusively empower, their
Keywords Teachers' Competency, Technical and Vocational Education and Training (TVET), Vocational Teacher, Employability, Marketability

\section{Introduction}

The decisive role of a teacher has called upon the necessity to employ a range of measurement standard and accreditation to ensure the students that graduate from a certain program meet employer requirements. TVET teachers, teachers who teach vocational stream subject at vocational colleges, first paid little attention to the fact that their roles in producing skilled human capital are prevalent. The existent of TVET teachers who previously graduated from skill institutions were being left out from the teaching profession mainstream due to government focus on secondary school educational stream, which is mainly based on science and art field. With government efforts to produce more skilled employees, teacher preparation undergraduate program of a more skilled-based subject has been fostered. This proactive 
action has contributed to numbers of graduated TVET teachers, who hold bachelor's degree program in education and hold major in technical-based subjects such as automotive engineering, cosmetology, culinary arts, air-conditioning system, and other engineering-based subjects through Malaysian Skills Certificate, known as Sijil Kemahiran Malaysia (SKM). However, most teachers, who come into the teacher's preparation program are selected from various educational certification levels (Malaysian Higher Secondary School Certificate, Matriculation, and Diploma). In addition, some of the pre-service teachers do not obtain certain fundamental knowledge on the technical-based subject, which make them struggle while doing their undergraduate program. The students who come from Malaysian Higher Secondary School level also known as Sijil Tinggi Pelajaran Malaysia (STPM) for example, originate from two major mainstreams: Science and Business Accounting. When they entered the undergraduate program in technical-based subjects, it is safe to claim that they are struggling not only to master the knowledge and technical subject but also the pedagogical knowledge for teaching and learning preparation.

In most schools, the options to teach given to the newly-appointed teachers are heterogeneous, with regards to the available position at the school. This environment also effects vocational colleges. It was reported that in order to just 'fit-in' the teacher intake at vocational colleges, the new teachers have been posted to various programs major. The inconsistency of the undergraduate program enrolled by the teachers frequently leave the teachers which doubted of their capability to teach a subject beyond their expert area (Nespor, 2013). A teacher who possessed their undergraduate program from technical-based subjects have been requested to teach art stream as such contributed to maladjusted which disadvantaging the expert area of such teacher. This unfair treatment for newly-appointed teacher has produced anxiety and lack of motivation to the teacher to teach which ultimately neglecting their competency of unintended teaching beyond their subject-matter expert.

The pertaining issue of incompetent teachers will reflect upon the government policy to empower the TVET master plan for the nation. The $11^{\text {th }}$ Malaysian Plan reported that the increase in the employment sector, especially in TVET sectors, will more likely to increase in years to come. The status of becoming a well-developed nation will be reflected upon the capability and capacity of such nations to produce skilled human capital. Hence, to objectify the mission, the Malaysian government has introduced and reinforced the Education Development Plan Malaysia (PPPM) 2013-2025 to empower the education system. One of the pillars of this plan is to strengthen TVET-based education. One of the actions undertaken by the government is to revamp the existing TVET curriculum and rebranding the vocational education to TVET Malaysia (Omar, Mat Rashid, \& Puad, 2018). The access to quality education has been opened to all grassroots through Education Development Plan Malaysia (PPPM) 2013-2025 and transformation plan was brought on the table by benchmarking the international standard (Malaysia, 2013). This plan will mirror the vision of the system education and aspirations of students who will be able to meet their needs and wants the country in the future that includes the TVET system.

The government method for handling the lack of skilled manpower implies more than giving to TVET teachers the best solution. TVET teachers have been encouraged to participate in teacher induction program to increase their technical and pedagogical skills. TVET teachers have been urged to fulfilling themselves with the latest technology and information especially aligning with the Industrial Revolution 4.0 needs. They are required to upscale and revisioning the future job trend to help graduates getting a job. Undoubtedly, to produce more skilled and semi-skilled workforces for the nation, a teacher must scrutinize and highly proficient in gaining knowledge, developing skills and prospering positive attitudes. This is parallel and tune-up into the strategic and operational planning for PPPM 2013-2025 to produce competent teachers.

The government plan to develop and empower skilled and semi-skilled manpower requires precocious strategy and partially reform in the educational curriculum. One of the actions undertaken by the government is to transform TVET to serve educational stakeholders needs in the nation; preparing for the workforce (Malaysia, 2013). One step forward is to strengthen networking with the industry by providing on-going training to teacher and students. A total evamps on the assessment and evaluation process as well as and comprehensive review of the existing curriculum was executed. In order to prepare students for work placement, Samsudin (2008) suggested that the integration of knowledge and skills is necessary for TVET-based educational system. On the basis of the needs to compensate for the $21^{\text {st }}$ century skills-to-work readiness, graduates are required to master employability skills.

It is agreeable by the market trend that the employability skills of graduates are the key role in determining student's competency to work in the industry. Employability skills can be defined as transferable skills that can be applied in any organization. The skills may include teamwork, negotiation, communication, thinking, social, and other soft-skills (Omar, Bakar, \& Mat Rashid, 2012). It is expected that the employability skills traits might everchanging by years due to the advancement of technology and ways of people communicating as well as doing businesses. Therefore, the educational system has been called upon to fulfill the graduate's employability skills by embedding employability skills academic, personal and teamwork skills that employers expect from 
their employees (CBC, 2000). Forthwith by the scenario, educators at any educational levels must portray and exercise the employability skills so the students will have exposure to real-life employment settings.

The fundamental of TVET is based on the integration of knowledge and skills which hold the principle of holistic education approach. At the premise of reinforcing the skills of TVET educators at TVET institutions, educational stakeholders must organize a comprehensive transformation of the program to ensure the objective to produce human resources that able to work professionally and competently in the industry is achievable. Thus, the competency of TVET educators is crucial because they are the main entity to objectify the mission. Based on stated elements, it is clear that individuals must have sufficient knowledge, high skills and a good composure of attitude to compete globally. In the context of education, the energy of the instructor that flows during teaching and learning contexts prosper an effective learning environment. Subsequently, the teachers who possess competency traits able to deliver the TVET curriculum which commonly divides into two main aspects which calculated in percentage form; $70 \%$ of vocational skills and $30 \%$ of academic knowledge. Areas that offered in most TVET institutions including Electric and Electronic Technology, Machining Industrial Technology, Welding Technology, Automotive Technology, Refrigeration and Air Conditioning Technology, Construction Technology, Computer Systems and Networks, Database Management Systems and Web Applications and Culinary arts, aligning with the experts needed by the industries.

It is evident that the requirement to have competent teachers especially in TVET educational institutions is essential. The nature of teaching and learning of environment in TVET which highly emphasized on practical-based will determine whether or not the student learned the skill they need for employment. As the student pursuing their higher degree, the curriculum they learned throughout their TVET institutions accelerates their accumulation of theoretical and practical knowledge. However, to fulfill this mission, the teacher must competent in knowledge, skills, and attitudes of TVET curriculum. Therefore, this article proposed a quantitative study to determine the level of TVET teacher's competency and indicate the best competency traits to be explored by teachers. It is hoped that the findings would serve as a benchmark for TVET division at ministry level to improvise and advise the TVET teachers' competency and encourage the importance of knowledge, skills, and attitudes among teachers while performing their core-business as teacher.

\section{Literature Review}

In the past years, the topic of teacher's competency has attracted much attention among researchers and become the main concern among educational stakeholders. The pertinent facts from the research findings indicated salient contributions of understanding teacher competency in the teaching profession. Boyatzis (1982) and Quinn, Mathur, and Rutherford (1996) described competency as a composure of knowledge elements (cognitive), skills (psychomotor), practical understandings and attitudes (affective) are shown in behavior forms when doing something. Previous studies reported numerous competency traits as to depict the current teaching arena (see Low, Ng, \& Li, 2016; Nousiainen, Kangas, Rikala, Vesisenaho, 2018; Zanella, Antonelli, \& Bortoluzzi, 2017). The researchers jostled the research context within teacher competency, implored the necessary action towards understanding teacher's competency to improve teaching and learning environment. Arifin (2010) indicated the pivotal role of competency consisting knowledge, skills, and attitudes as characteristic and personality that must be possessed by one person to showcasing his or her competent in fulfilling the designated job. The main purpose of competency is to enable someone to perform more tasks effective and effective at their optimum level. In addition to that, skills that effect work performance normally regarded as intelligence-based capabilities that portray one's competency traits (Arifin, 2010). As soon as the teachers master the knowledge, skills, and attitudes of subject-matter and designated teaching task, they could get the fact that they matured the competency traits that able to certify them as a teacher.

According to the International Board of Standard for Training, Performance, and Instruction (2006), competence is the knowledge and attitude that can conduct an activity and be able to set up a set of solid skills based on his achievements. The performance of an individual who serves as a teacher will increase if the individual has a level high competence to carry out the duties and responsibilities of the classroom. Nousiainen, Kangas, Rikala, and Vesisenaho (2018) explained teacher competency as core elements of the teaching profession. In the context of teacher education preparation program and in-service training program, they regarded four main competence as the results from the study: pedagogical, technological, collaborative and creative. A cursory analysis by the researchers revealed an orderliness and a structure teaching strategy that accumulate competent teacher which is highly necessary for the $21^{\text {st }}$ century teaching agenda. For example, teaching in a particular must integrate the pedagogical knowledge with existing technology produce a significant impact on the learning outcome (Ertmer \& Ottenbreit-Leftwich, 2010). Despite the tools that engage the student, socially involved in teaching and learning context encourage the teacher-student relationship. It is evidence that the teacher plays a huge role in fostering student interaction and 
creating boundaryless student contact via collaborative learning (Kaendler, Wiedmann, Rummel, \& Spada, 2015). The social context is vital not only for students but also for teachers to encourage their participation in the classroom context to ensure meaningful teaching is served.

Research findings by Low, $\mathrm{Ng}$, and $\mathrm{Li}$ (2016) also pointed out towards the comprised of knowledge, skills, and attitudes as core competencies. The findings indicated that statistically significant increases in perceived levels of key professional competencies including pedagogical content knowledge, classroom management, use of Information, Communication, and Technology (ICT) in teaching, and reflection among pre-service teachers. The findings were corroborated with the study from Ertmer and Ottenbreit-Leftwich (2010) which regarded the accumulation of pedagogical context and use of technology significantly improves teacher's competency. However, Low, Ng, and $\mathrm{Li}$ (2016) further discussed competencies achievement of the pre-service teachers is evident that they were struggling with school operation and understanding how the school is operated. It appears to the aforementioned investigation that most attention must be paid to support system that assists collegial support among the new teachers and help them to remain in the school system as well as a prolonged school teaching experience to strengthen theory-practice nexus is necessary (Low, $\mathrm{Ng}, \& \mathrm{Li}, 2016$ ).

The normally enthusiastic classroom environment was deeply involving a teacher who able to deliver the learning content in most effective and attractive techniques. Students are determined to see that teacher is able to create a positive classroom environment and comprehensive learning content. Zanella, Antonelli, and Bortoluzzi (2017), at the findings of students, teacher's competency was determined based upon interpersonal relationship, commitment, mastery of the area, ethics and didactic-pedagogical that the student exercise in teaching and learning context. Student place high expectation of teachers' credibility when it comes to the classroom environment. The research by Peklaj (2019) also pointed out the necessary competencies for developing optimal learning environments for students and for promoting key competencies in students that will enable them to be successful in the rapidly changing society in the $21^{\text {st }}$ century. This mission can be achieved if the teacher able to revisiting their talents and capabilities through the induction program and ultimately develop their competency traits that fulfill student motivation to learn in the classroom.

While it is important to understand the capabilities and capacities as what can be considered a 'best' teacher, Karft (2019) argued on the transferable skills that have been developed on students. Despite having many discussions on what the teachers could offer in ensuring the academic knowledge is well-versed in teaching and learning context, Kraft (2019) suggested that it is important for students to develop cognitive skills and social-emotional competencies, those skills that are required in $21^{\text {st }}$ century workforce skills. The well-informed teacher who able to exercise students' talents in the aspects of workforce skills is elapsed in ways of ignorance rather focusing on standardize testing and student's performance by the grading system. Therefore, effects on students' performance on complex open-ended tasks in math and reading, as well as their growth mindset, grit, and effort in class are essential to developing workforce skills as required by the industry. Kraft (2019) also reported that large teacher effects across this expanded set of outcomes, but weak relationships between these effects and performance measures used in current teacher evaluation systems including value-added to state standardized tests, which indicated unbalance student's outcome and fail to fulfill the industry needs.

It is undoubtedly important for teachers to develop complex instructional, classroom management, communication, and assessment competencies so as to facilitate students' cognitive, affective and social processes (Peklaj, 2015). On another note, Bakar, (1995) also agreed that competent educators are those who have a warm attitude to their students, carers, responsible, high discipline, and decent communication skills. This means that an excellent teacher should have the values, pure values naturally because teachers are exemplary of students during the teaching and learning process. Despite having a deeper understanding of their subject matter, the effects of their own teaching on students, it is vital to develop sense of belonging and positive rapport with students that ultimately direct teachers to increase their passion for teaching and learning, as well as respected their students, and they developed a positive classroom climate that fostered learning (Peklaj, 2015).

Teachers competency has greatly emphases on three elements; knowledge, skills, and attitudes. These three elements are interconnected between one after another. If a teacher does not have one of these elements, it is safe to convince that the teacher must undergo training to achieve the stated competencies. As the competency traits as being justified in the study are prominent elements in a field of teacher competency research trend, teachers are bound to this competency elements and must be trained accordingly. As tangible evidence depicting the TVET based curriculum which consists of theoretical and practical knowledge, it is time to called upon this group of teachers to be part of the research project. TVET teachers hold responsibility for giving training of practical teaching practices in the workshops are important to produce skilled students. Therefore, it is advisable that TVET teachers must nobly competent in academic knowledge but also practical knowledge subsequently ensuring the 
teaching and learning process can be carried out effectively. Furthermore, to ensure more lecturers are competent, they must master the practical pedagogical methods which are discussed in this paper, therefore, encourage meaningful practical teaching and learning process at the workshop and maintaining the competency of teachers at all time.

\section{Methodology}

A quantitative survey method was employed to gather information from the TVET teacher in Selangor, Malaysia. A questionnaire was distributed to TVET teachers who teach the vocational-stream subject and emphasizing on practical-based teaching and learning context. Statistical Package for Social Science (SPSS) version 22 was used to analyze the data and to inform the research findings based on the inquiry on teacher's competency. The study was conducted in three vocational colleges in Selangor. The three vocational colleges were chosen based upon the suggested two criteria on the characteristics of the program conducted at the vocational colleges. The first criteria were the three vocational colleges was selected due to accredited as 'Skills Vocational College' by the TVET division at the ministry level. Secondly, the teachers who selected to participate in this study is a teacher who teaches the practical-based subject at a lab or workshop. The population size that involved in this study was 247 teachers who mainly teach vocational-stream subjects. From this number, 150 teachers were drawn using a random sampling technique. The questionnaire was divided into four parts: (a) demographic/background of the respondents, (b) questions related to knowledge aspect, (c) questions related to the skills aspect, (d) question regarding attitude aspect, and (e) practical teaching practices. Five-point Likert type scale was used to interpret the data for each variable. The score was divided into three range of scoring index: (a) 1.00 to 2.49 is interpreted at a low level, (ii) 2.50 to 3.49 interpreted at a medium level and (iii) 3.50-5.00 interpreted at a high level. The questionnaire was adapted and replicated from Mulford and Edmund (2009), Abdul Khalil (2017), and Mohd Ridhuan (2007) studies on teachers' competency. Permission was obtained from instrument developer prior study. A pilot study was conducted on 30 respondents (who were not taking part in the actual study) to test the set of questionnaires before the actual survey was distributed to the respondents as well as to determine the validity and reliability of the research instrument. The purpose of conducting the pilot study is to evaluate consistency (reliability) items of aspects, item level, objective, item understanding, the usability of the item and the instruction of the item itself (Chua Yan Piaw, 2006). Based on the reliability index, the instrument was at $\alpha=0.77$, a good determinant factor for the planned study.

\section{Results and Findings}

\section{Research Findings 1: Demographic Factor}

The data analysis was carried out using descriptive analysis which includes percentage, mean score and standard deviation. In defining the respondent's demographics factor; gender, age, race, education level and years of teaching experience of the teachers were asked in the survey. Table 1 showed the result of the analysis of demographic data in detail about the distribution of respondents' demographics according to each factor.

Table 1. Data Distribution of Respondents' Demographic Background

\begin{tabular}{|c|c|c|c|}
\hline \multicolumn{2}{|c|}{ Demographic characteristics } & \multirow{2}{*}{$\begin{array}{c}\text { Frequency } \\
98\end{array}$} & \multirow{2}{*}{$\frac{\text { Percentage }(\%)}{65.3}$} \\
\hline & Male & & \\
\hline Gender & Female & 52 & 34.7 \\
\hline \multirow{4}{*}{ Age } & 20-30 years old & 33 & 22.0 \\
\hline & $31-40$ years old & 45 & 30.0 \\
\hline & 41-51 years old & 56 & 37.3 \\
\hline & 51 years old and above & 16 & 10.7 \\
\hline \multirow{4}{*}{ Race } & Malay & 138 & 92.0 \\
\hline & Chinese & 7 & 4.7 \\
\hline & Indian & 5 & 3.3 \\
\hline & Others & - & - \\
\hline \multirow{4}{*}{ Education } & Bachelor's Degree & 107 & 71.3 \\
\hline & Master's Degree & 36 & 24.0 \\
\hline & Ph.D. & - & - \\
\hline & Others teacher certification program & 7 & 4.7 \\
\hline \multirow{4}{*}{ Teaching Experience (in years) } & 1 to 5 years & 29 & 19.3 \\
\hline & 6 to 10 years & 27 & 18.0 \\
\hline & 11 to 15 years & 24 & 16.0 \\
\hline & 16 years and above & 70 & 46.7 \\
\hline
\end{tabular}




\section{Research Findings 2: What is the level of knowledge competence of TVET teachers based on practical teaching practices?}

The SPSS software calculated the mean score to derive the competency level of TVET teachers on the knowledge aspect. The value of the mean score was obtained and interpreted according to the predetermined level by the 5-point Likert-scale. Researcher represented the questionnaire in the form of the category where section $\mathrm{B}$ is predetermined as the knowledge section. The questions were labeled as B1 to B10 to determine that there were 10 questions on that section. Part B, particularly, is a knowledge aspect which was measured using the level of teacher's competence. The knowledge competency covered pedagogical, demonstration, and presentations of teaching practices in a practical workshop environment. The results and detailed of the constructs were described in table 2 .

Table 2. Level of Knowledge Competence among TVET Teachers

\begin{tabular}{|c|c|c|c|}
\hline No. & Item & M & S.D. \\
\hline B1 & $\begin{array}{l}\text { I am knowledgeable in applying } \\
\text { demonstration teaching method during a } \\
\text { practical-based learning environment }\end{array}$ & 4.09 & 0.58 \\
\hline $\mathrm{B} 2$ & $\begin{array}{l}\text { I am knowledgeable in facilitating students } \\
\text { during a practical-based learning } \\
\text { environment }\end{array}$ & 4.21 & 0.41 \\
\hline B3 & $\begin{array}{l}\text { I always seek for experts' opinion to } \\
\text { enhance my knowledge }\end{array}$ & 4.07 & 0.52 \\
\hline B4 & $\begin{array}{l}\text { I am capable to apply my current } \\
\text { knowledge via teaching and facilitating } \\
\text { processes }\end{array}$ & 4.31 & 0.53 \\
\hline B5 & $\begin{array}{l}\text { I am willing to share my knowledge with } \\
\text { my co-workers }\end{array}$ & 4.01 & 0.57 \\
\hline B6 & $\begin{array}{l}\text { I am interested to learn existing and latest } \\
\text { technologies }\end{array}$ & 4.41 & 0.49 \\
\hline B7 & $\begin{array}{l}\text { I am well-acquainted with managing the } \\
\text { student internship }\end{array}$ & 4.19 & 0.61 \\
\hline B8 & $\begin{array}{l}\text { I have the ability to operate the equipment } \\
\text { in my workshop }\end{array}$ & 4.22 & 0.55 \\
\hline B9 & $\begin{array}{l}\text { I am good at applying Standard Operating } \\
\text { Procedure (SOP) and handling equipment }\end{array}$ & 4.15 & 0.67 \\
\hline B10 & $\begin{array}{l}\text { I am knowledgeable in using various } \\
\text { practical teaching and learning strategies to } \\
\text { stimulate student interest }\end{array}$ & 4.30 & 0.59 \\
\hline & Total Mean & 4.20 & \\
\hline
\end{tabular}

\section{Research Findings 3: What is the level of skill competence of TVET teachers based on practical teaching practices?}

In order to determine the level of skills competence among TVET teacher, the researcher developed section $\mathrm{C}$ by dividing the construct into 10 items; $\mathrm{C} 1$ to $\mathrm{C} 10$. The SPPS calculated the value of mean which represents the level competence of lecturers from skills aspect. This section emphasized on skills possession of TVET teachers in teaching the vocational-based subject in the workshop. The detail of the findings is described in table 3 .

Table 3. Level of Skill Competence among TVET teachers

\begin{tabular}{|c|c|c|c|}
\hline No. & Item & $\mathbf{M}$ & S.D. \\
\hline $\mathrm{C} 1$ & $\begin{array}{l}\text { I am able to interact with my students } \\
\text { by transmitting the hands-on knowledge } \\
\text { that I know }\end{array}$ & 4.03 & 0.58 \\
\hline $\mathrm{C} 2$ & $\begin{array}{l}\text { I have skills and competent in my field } \\
\text { of expertise }\end{array}$ & 4.30 & 0.46 \\
\hline C3 & $\begin{array}{l}\text { I am able to diversify my teaching } \\
\text { strategies to students to understand the } \\
\text { learning content }\end{array}$ & 4.43 & 0.50 \\
\hline $\mathrm{C} 4$ & $\begin{array}{l}\text { I have the skills to help students learned } \\
\text { using technological equipment like } \\
\text { machines in the lab }\end{array}$ & 4.30 & 0.46 \\
\hline $\mathrm{C} 5$ & $\begin{array}{l}\text { I am good at demonstrating equipment } \\
\text { during practical teaching and learning } \\
\text { environment }\end{array}$ & 4.30 & 0.59 \\
\hline C6 & $\begin{array}{l}\text { I am creative in teaching } \\
\text { practical-based subject }\end{array}$ & 4.31 & 0.53 \\
\hline $\mathrm{C} 7$ & $\begin{array}{l}\text { I am always ready and eager to improve } \\
\text { my skills }\end{array}$ & 4.30 & 0.59 \\
\hline $\mathrm{C} 8$ & $\begin{array}{l}\text { I am always coping with the latest } \\
\text { technological changes and trying to } \\
\text { improve my skills }\end{array}$ & 4.02 & 0.57 \\
\hline $\mathrm{C} 9$ & $\begin{array}{l}\text { I have the skills to apply safety } \\
\text { practices in the workshop }\end{array}$ & 4.23 & 0.50 \\
\hline \multirow[t]{2}{*}{$\mathrm{C} 10$} & $\begin{array}{l}\text { I am good at explaining about learning } \\
\text { content related to skills practices }\end{array}$ & 4.33 & 0.53 \\
\hline & Total Mean & 4.26 & \\
\hline
\end{tabular}




\section{Research Findings 4: What is the level of attitude among TVET teachers based on their practical teaching practices?}

The researcher coded section D into 10 items using D1 to D10 to describe attitude levels among TVET teachers. This section discussed the attitude that becomes the determinant factor of competency level among TVET teachers. An insightful and responsible for the task as such was developed as a construct. Table 4 described the findings in detail.

Table 4. Level of Attitude Competence among TVET Teachers

\begin{tabular}{|c|c|c|c|}
\hline No. & Item & M & S.D. \\
\hline D1 & $\begin{array}{l}\text { I have always been positive about } \\
\text { practical teaching practices }\end{array}$ & 4.43 & 0.50 \\
\hline $\mathrm{D} 2$ & $\begin{array}{l}\text { I able to manage students' disciplinary } \\
\text { issues during practical teaching practices }\end{array}$ & 4.29 & 0.46 \\
\hline D3 & $\begin{array}{l}\text { I am ready to join additional practical } \\
\text { courses to improve my skills }\end{array}$ & 4.29 & 0.60 \\
\hline D4 & $\begin{array}{l}\text { I am always eager to encourage my } \\
\text { students to participate in a } \\
\text { practical-based learning environment, } \\
\text { therefore, they will be able to produce a } \\
\text { quality product }\end{array}$ & 4.19 & 0.51 \\
\hline D5 & $\begin{array}{l}\text { I always make sure that the equipment is } \\
\text { in good condition before I use it. }\end{array}$ & 4.01 & 0.59 \\
\hline D6 & $\begin{array}{l}\text { I am always ready to brief students on } \\
\text { safety practices at the workshop. }\end{array}$ & 4.41 & 0.51 \\
\hline D7 & $\begin{array}{l}\text { I always teach my students first before } \\
\text { carrying out a practical task. }\end{array}$ & 4.31 & 0.47 \\
\hline D8 & $\begin{array}{l}\text { I fulfilling my task with full } \\
\text { responsibility and honesty }\end{array}$ & 4.31 & 0.59 \\
\hline D9 & $\begin{array}{l}\text { I able to maximize my teaching hour } \\
\text { wisely }\end{array}$ & 4.14 & 0.66 \\
\hline \multirow[t]{2}{*}{ D10 } & $\begin{array}{l}\text { I expose students to out-of-school } \\
\text { programs like bringing them for } \\
\text { industrial visit }\end{array}$ & 4.32 & 0.47 \\
\hline & Total Mean & 4.26 & \\
\hline
\end{tabular}

\section{Research Finding 5: What is the best predictor among knowledge, skills, and attitudes toward determining TVET teacher's competency in practical teaching practices?}

The following analysis was conducted to identify the best predictor among knowledge, skills, and attitude towards TVET teacher's competency based on practical teaching practices in the workshop. A multiple linear regression analysis was conducted to evaluate knowledge, skills, and attitudes as predictor variables towards TVET teacher's competency using significant coefficients. The result of multiple regression analysis shows that the regression model consisting knowledge, skills, and attitudes related to the teacher competency plan, $[\mathrm{F}(3,168)$ $=31.16, \mathrm{p}<0.05]$. However, the results revealed that only knowledge was found significant i.e. $(\beta=0.234, t=2.927$, $\mathrm{p}<0.05)$, whereas skill $(\beta=0.094, \mathrm{t}=1.152, \mathrm{p}=0.251)$ and attitude i.e. $(\beta=0.083, \mathrm{t}=1.010, \mathrm{p}=0.314)$ were found insignificant at $p<0.05$. Based on the beta value in this study, the knowledge factor $(\beta=0.234)$ is the best predictor in teaching the practical-based subject at the workshop. The equation for the current regression analysis is:

$$
\mathrm{Y}_{\mathrm{i}}=0.234_{\mathrm{x} 1}+0.198_{\mathrm{x} 2}+0.176_{\mathrm{x} 3}+0.40
$$

where,

$$
\begin{aligned}
& \mathrm{Y}_{\mathrm{i}}=\text { Practical teaching practices } \\
& \mathrm{x} 1=\text { Knowledge } \\
& \mathrm{x} 2=\text { Skill } \\
& 3=\text { Attitude }
\end{aligned}
$$

Table 5. Regression Analysis on Three Predictors

\begin{tabular}{cccccc}
\hline Source & B & $S E B$ & $\beta$ & $t$ & $p$ \\
\hline Knowledge & 0.402 & 0.137 & 0.234 & 2.927 & $0.004^{*}$ \\
\hline Skill & 0.198 & 0.172 & 0.094 & 1.152 & 0.251 \\
\hline Attitude & 0.176 & 0.174 & 0.083 & 1.010 & 0.314 \\
\hline
\end{tabular}

*significant at $\mathrm{p}<0.05$

\section{Discussion}

Evaluating teachers' competency is as important as we evaluate students' performance in the classroom. Notwithstanding, the important role teachers play at school as the frontline individual to produce a significant impact in educating the future generation of the nation. This study spells out the important teachers' competency traits and determines as to what extent the TVET teachers are competent from the three aspects; knowledge, skills, and attitude towards teaching in a practical-based education in a workshop. In general, the result of the study analysis shows the level of competence of TVET teachers in terms of the three competency traits is at a high level. The comparative analysis and item comparisons were analyzed to see the significant relationship to the competence of vocational college teachers based on practical-based learning environment. However, the matters that highlights the most in this section is based upon the results of the relationship of knowledge and TVET teacher's competency in practical teaching practices which was found significant. Consistent with findings by previous researchers, which will be discussed later in this section, the researcher reflects and discuss the possible explanations of the findings. Among the plausible explanation of some of the findings, it is interesting to note that there was no significant relationship of the teacher's skills and attitude competence in regards to the practice of practical teaching in the workshop at the TVET institution.

Teacher knowledge competency marks essential asset of TVET competency and accosted by various reasons, for example, the educational background of the teacher, pedagogical knowledge possession, and personal construct of talents and abilities. Suppose a teacher come to an understanding to possess knowledge on the subject matter, findings suggested the knowledge competency covers a 
wide array of what the researcher presume as tacit and explicit knowledge to teach. The teacher's knowledge competency become a crucial element because the idea of knowledge at school comprises broaden fields that constitute the academic curriculum, pedagogical knowledge and personal paradigm of teachers are those diverse characteristics to determine the effectiveness of teacher (Banks, Leach, \& Moon, 2005). The practice of teaching has awakened the needs for teachers to participate and obey the over changing teaching approaches due to rapid technological tools and machinery that embarks salient knowledge competency of teachers to master this knowledge. Despite, not only to teach, it surprisingly that reconceptualization of the teaching profession has brought upon teachers' responsibility to carry out research, involve in career professional development program, leadership role, just to name a few, as a matter of fact, the spirit to develop teachers' knowledge and competency.

The notion of that teachers is not competent is somewhat contradicts with some of the people beliefs. A teacher by chance received a well-trained on a subject matter and pedagogical knowledge, hence they certified to be a teacher. In fact, most teachers in some countries hold a bachelor's degree in education with a minor in the prospective field. This eminent step is to ensure teachers are able to teach effectively. However, research reported that teachers struggle to demonstrate their competency although being trained number of years. Findings reported that they were lack of pre-service preparation or professional staff development opportunities, where administrators, teachers, and paraprofessional similarly reported that the skill and knowledge competencies to be important for teachers who direct the work especially for paraprofessionals group (Wallace, Shin, Bartholomay, \& Stahl, 2001).

The skeptical beliefs of teachers that 'all children can learn' has awaken people assumption that the concept of a school for all is relevant. Therefore, teachers are called upon to diversify their knowledge to cater to the boundaryless scope of teaching and enhance their pedagogical skills (Banks, Leach, \& Moon, 2005). The gamut of teaching techniques promotes the creativity of teachers to cater to students with different needs. For example, despite the gap of knowledge and action of teachers in responding to student's inquiry, acquiring of knowledge especially theoretical and practical knowledge is important. However, often knowledge acquired in settings of teacher education, initial teacher education as well as in-service teacher training are missing and often misinterpreted by teachers (Wahl, 1991, Wahl, 2000, Wahl, 2001 as cited in Vogt \& Rogalla, 2009). Without the fundamental knowledge to be a teacher, the teacher might struggle in the early stage of their career which frequently contributed to maladjustment and frustration.

A novice teacher, a group of teachers who just entered the teaching profession first paid little attention to the fact that whatever they learn from the teacher's preparation program is going to be totally different with the real-life school environment. In most schools especially in Malaysia, the program is quite heterogeneous with teacher's expert area. It is often to witness that the teacher's arrangement to school frequently mismatched with their expertise and is based on available vacancy. However, teachers were frequently disparaging by the school decision. As Vogt and Rogalla (2009) pursued their investigation on this phenomenon discovered that it is important for teachers to corroborate with the adaptive teaching competency. The adaptation knowledge is important to help the teacher get adopted with the school system. The idea to have a practical teaching internship at school is one way of encountering unstable fresh teachers. Because teachers' action assume that teachers' knowledge is not stored in the memory as in an encyclopedia, but rather is linked to a specific situation and is implicitly triggered by a certain action, built upon the basis of teaching experiences (Groeben et al., 1988, Heider, 1958, Neuweg, 1999). Without having the pre-teaching experience, the teacher might lose their interests in teaching and leave the teaching in the early years of their profession.

Speaking in critical notion, teacher's profession has been wrestled with numbers of teacher's dropout for many years. Many studies have portrayed the reason as to why teachers leaving the teaching profession. Some of the reasons attributed to retirement, relocations, and career changes there are further reasons why, for such a credible professional, teachers are leaving (Billingsley, 2004; Gomba, 2015; Ingersoll \& Strong, 2011; Ingersoll \& Educational Resources Information Center, 1999; Omar, Rashid, \& Puad, 2018; Perrachione, Petersen, \& Rosser, 2008). The lackluster teacher's profession program has been blaming due to this on-going issue. A beginning teacher support programs, also known as teacher induction programs have been carried out over the years to counter the problem. The objective of this program is to take the opportunity of teacher's resentment and dissatisfaction as well as enhance their motivation to teach. It is proven that such programs can improve teacher retention rates by enhancing new teacher satisfaction (Stansbury \& Zimmerman 2000). In another context, the induction program able to help new teachers applying the theoretical knowledge acquired in their teacher preparation program to the complexity of real-life teaching (Stansbury \& Zimmerman 2000; Vogt \& Rogalla, 2009).

The rudimentary aspect of strong knowledge on subject-matters is vital to ensure that teachers are able to deliver effective teaching and learning instructions. TVET teachers who embrace skilled-based knowledge on machinery and technological operation requires deep knowledge on the course content in order to teach vocational students. Tunuklu and Yesildere (2007) agreed 
on the integration of pedagogical knowledge and knowledge and subjects matter produce impactful learning environment. Wenner (1993) indicated that a low level of knowledge would produce a negative connotation between teaching academic knowledge and attitude toward teaching, and a marked lack of confidence toward teaching the subject-matter among the prospective teachers. It is interesting to note that, however, having a deep understanding of academic knowledge was necessary but not sufficient to teach the subject-matter. Tunuklu and Yesildere (2007) reiterated that the connection between knowledge of subject matter and knowledge of subject-matter teaching differs. It is suggested to consider the "pedagogical content knowledge" aspects as the key concern when it comes to effective teaching and learning instruction (Turnuklu\& Yesildere, 2007).

\section{Conclusions}

The presence of TVET teacher in the teaching profession is essential to supply skilled employees in the nation. Teaching the future generation cannot be taken for granted. This congenial contributions of TVET teacher in vocational stream is relevant to the national agenda to make TVET stream as primary education for the grassroots in Malaysia, As the educational system has been improvised from time-to-time, the role of TVET teacher consumes greater involvement from the educational stakeholders to increase the likelihood of them to be competent and reliable in the teaching profession. There is no way to hoard the significant role of TVET institutions; rather huge responsibility being placed by the government to implicate the future generation as what some developed country develops their human capital. Germany, the UK, and the United States are some countries with fast forward in many industries and become a player in manufacturing and technological inventions. Their fundamental idea of what should be in their educational system has become exemplary to developing nations. They successfully developed their human capital and optimize their capacities and capabilities with resources and investment. Hence, they also believe in placing trust in teachers to develop their future grassroots.

Based on the findings, knowledge becomes an important role in determining a teacher's competency. Although knowledge is possessed through educators' educational process, it also portrayed by the years of experience the teachers spend in the teaching profession. With experience in teaching, teachers are able to develop their continual knowledge by involving life-long earning by enrolling themselves in postgraduate programs and other courses to enhance skills and knowledge. The researchers also suggested that the TVET administration extends courses and training to lecturers either at vocational colleges or at other training institutions to empower their role as a teacher at the TVET institutions. This is due to essential points is that the practical teaching in the workshop requires a knowledgeable, skilled and positive attitudes lecturer on practical work. Through the training sessions, subsequently may increase the confidence level of teachers to teach practical-based subjects.

Accordingly, the researcher suggested that the vocational college administration support the mentor and mentee programs among new and senior teachers in order to facilitate the sharing of experiences and ideas. By prospering this initiative, new teachers would be able to improve their knowledge and skills not only in teaching but also with the school ecosystem. The enrichment of teachers' knowledge and skills in practical teaching would expect to produce highly skilled students as intended by the TVET system, thus responding to the government's call to produce more skilled and semi-skilled workforce. Future research can be placed upon the facilities and technology of TVET institutions has in order to support TVET teachers teaching and learning attributes and prosper the mastery knowledge of students in preparing them for future workforce is recommended.

\section{REFERENCES}

[1] Bakar, A. (1995). Teacher Preparation Concerns: Professional Needs of Malaysian Secondary School Science Teachers.

[2] Banks, F., Leach, J., \& Moon, B. (2005). Extract from new understandings of teachers' pedagogic knowledge.

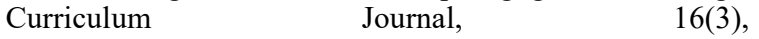
331-340.doi:10.1080/09585170500256446

[3] Billingsley BS (2004). Special education teacher retention and attrition: A critical analysis of the research literature. The Journal of Special Education 38(1), 39-55.

[4] CBC, 2000. Employability Skills Toolkit for the Self-managing Learner. 1st Edn., Conference Board of Canada, Ottawa, ISBN-10: 0070878471, pp: 10.

[5] Ertmer, P. A., \& Ottenbreit-Leftwich, A. T. (2010). Teacher technology change: How knowledge, confidence, beliefs, and culture intersect. Journal of research on Technology in Education, 42(3), 255-284.

[6] Gomba, C. (2015). Why Do They Stay: Factors Influencing Teacher Retention in Rural Zimbabwe. International Journal of Instruction 8(2), 55-68.

[7] Ingersoll, R.M., \& Strong, M. (2011), The impact of induction and mentoring programs for beginning teachers: A critical review of the research. Review of Educational Research 81(2), 201-33.

[8] Ingersoll, R., \& Educational Resources Information Center. (1999). Teacher turnover, teacher shortages, and the organization of schools a CTP working paper. Seattle, Wash.]: [Washington, DC]: Center for the Study of 
Teaching and Policy, University of Washington; U.S. Dept. of Education, Office of Educational Research and Improvement, Educational Resources Information Center.

[9] International Board of Standard for Training, Performance, and Instruction (2006). Instructor competencies. Retrieved from http://ibstpi.org/instructor-competencies/

[10] Kaendler, C., Wiedmann, M., Rummel, N., \& Spada, H. (2015). Teacher competencies for the implementation of collaborative learning in the classroom: A framework and research review. Educational Psychology Review, 27(3), 505-536.

[11] Kraft, M. A. (2019). Teacher effects on complex cognitive skills and social-emotional competencies. Journal of Human Resources, 54(1), 1-36.

[12] Low, E. L., Ng, P. T., \& Li, C. (2016). The contribution of teacher education in Singapore to the development of teacher competencies and Identity. Retrieved from https://repository.nie.edu.sg/bitstream/10497/18633/1/NIE _research_brief_16_007.pdf

[13] Omar, M. K., Bakar, A. R., \& Rashid, A. M. (2012). Employability skill acquisition among Malaysian community college students. Journal of Social sciences, $8(3), 472$.

[14] Omar, M. K., Rashid, A. M., \& Puad, M. H. M. (2018). Examining job satisfaction factors toward retaining Malaysian TVET instructors in the teaching profession. International Journal of Engineering \& Technology, 7(2.10), 44-49.

[15] Malaysia, K. P. (2013). Pelan Pembangunan Pendidikan Malaysia 2013-2025. (Online www. moe. gov. my).

[16] Nespor, J. (2013). Tangled up in school: Politics, space, bodies, and signs in the educational process. Routledge.

[17] Nousiainen, T., Kangas, M., Rikala, J., \& Vesisenaho, M. (2018). Teacher competencies in game-based pedagogy. Teaching and Teacher Education, 74, 85-97.

[18] Peklaj, C. (2015). Teacher Competencies through the Prism of Educational Research. Center for Educational Policy Studies Journal, 5(3), 183-204.

[19] Perrachione BA, Petersen GJ \& Rosser VJ (2008), Why do they stay? Elementary teachers' perceptions of job satisfaction and retention. The Professional Educator $32(2), 1$.

[20] Quinn, M. M., Mathur, S. R., \& Rutherford, R. B. (1996). Social skills and social competence of children and youth: A comprehensive bibliography of articles, chapters, books, and programs. Arizona State University.

[21] Stansbury, K., Zimmerman, J., \& Educational Resources Information Center. (2000). Lifelines to the classroom designing support for beginning teachers. San Francisco, Calif.]: [Washington, DC]: WestEd; U.S. Dept. of Education, Office of Educational Research and Improvement, Educational Resources Information Center.

[22] Turnuklu, E. B., \& Yesildere, S. (2007). The Pedagogical Content Knowledge in Mathematics: Pre-Service Primary Mathematics Teachers' Perspectives in Turkey. Issues in the Undergraduate Mathematics Preparation of School Teachers, 1 .
[23] Vogt, F., \& Rogalla, M. (2009). Developing adaptive teaching competency through coaching. Teaching and Teacher Education, 25(8), 1051-1060.

[24] Wallace, T., Shin, J., Bartholomay, T., \& Stahl, B. J. (2001). Knowledge and Skills for Teachers Supervising the Work of Paraprofessionals. Exceptional Children, 67(4), 520-533.doi:10.1177/001440290106700406

[25] Wenner, G. (1993). Relationship between science knowledge levels and beliefs toward science instruction held by preservice elementary teachers. Journal of Science Education and Technology, 2(3), 461-468.

[26] Zanella, P., Antonelli, R. A., \& Bortoluzzi, S. C. (2017). Assessment of Teacher Competencies: Analysis in the Accountancy Program at UTFPR. Revista de Educação e Pesquisa em Contabilidade, 11(2) 